Please quote as: Lehmann, K.; Söllner,M. \& Leimeister, J. M. (2016): Design and Evaluation of an IT-based Peer Assessment to Increase Learner Performance in Large-Scale Lectures. In: International Conference on Information Systems (ICIS), Dublin, Ireland. 


\title{
Design and Evaluation of an IT-based Peer Assessment to Increase Learner Performance in Large-Scale Lectures
}

\author{
Completed Research Paper
}

\author{
Katja Lehmann \\ University of Kassel \\ Pfannkuchstrasse 1, D-34121 Kassel \\ katja.lehmann@uni-kassel.de
}

\author{
Matthias Söllner \\ University of St.Gallen / \\ University of Kassel \\ Unterer Graben 21, CH-9000 St.Gallen \\ Pfannkuchstrasse 1, D-34121 Kassel \\ matthias.soellner@unisg.ch / \\ soellner@uni-kassel.de
}

\author{
Jan Marco Leimeister \\ University of St.Gallen / University of Kassel \\ Unterer Graben 21, CH-900o St.Gallen /Pfannkuchstrasse 1, D-34121 Kassel \\ janmarco.leimeister@unisg.ch / leimeister@uni-kassel.de
}

\begin{abstract}
In this study, we propose an IT-based peer assessment (ITPA) for enhancing interaction and feedback in universities' large-scale lectures. These lectures often lack interaction and feedback, and focus on mainly imparting factual knowledge. Hence, these formats often cannot go beyond the basic cognitive levels of educational objectives. Using the ITPA within the learning process helps integrating assignments focusing on high cognitive levels to comprehensively acquire the learning content. We follow a design science research approach to develop and evaluate the ITPA. Thus, we first identify requirements from theory and derive a set of design elements afterwards. A pre-test shows that the ITPA is seen as useful and learners intend to use it. The subsequent quasiexperiment in a large-scale lecture shows that learners who participated in the ITPA performed better in the part of the final exam trained by the ITPA, whereas they did not perform better in the others parts.
\end{abstract}

Keywords: IT-based peer assessment, technology-mediated learning, large-scale lectures, learning performance, educational objectives, design science research

\section{Introduction}

Large-scale lectures are still common default at universities worldwide, especially in basic lectures at an undergraduate level (Fortes and Tchantchane 2010; Van De Grift et al. 2002). Due to an uneven lecturerlearner proportion of sometimes more than 80 learners per lecture, those lectures lack feedback and interaction during the learning process (Bligh 2000). Furthermore, the imparting of knowledge is unidirectional from the lecturer to the learners, thus adopting a more or less passive learner role in the learning process (Ebert-May et al. 1997). In these large-scale undergraduate lectures, the imparting and verification of knowledge aim primarily at factual knowledge, both in assignments during the learning process as formative assessment as well as summative assessment in the final exam (Hagstrom 2006). 
However, solely focusing on factual knowledge limits the learning outcomes to the basic cognitive levels of educational objectives developed by Bloom et al. (1956). Modified by Anderson et al. (2001), the cognitive levels of educational objectives are as follows: remembering, understanding, applying, analyzing, evaluating, and creating. Whereby remembering, understanding, and applying are the basic cognitive levels, analyzing, evaluating, and creating are the high cognitive levels of educational objectives (Jaillet 2009). In this paper, we rely on these cognitive levels of educational objectives based on Anderson et al. (2001). However, the sole imparting and verification of knowledge regarding factual knowledge is problematic, even in basic courses or at undergraduate levels, because it is not sufficient with regard to the further study process as well as the tasks of employees of future daily business (Chiru et al. 2012). Higher education requires learners who are highly knowledgeable individuals as well as autonomous and self-regulated learners. The daily business requires employees with skills in complex problem solving, critical thinking, self-reflection, evaluating others, cooperating, self-regulation, and information technology use (Johnson et al. 2016; Schwab and Samans 2016). As a consequence, nowadays, even largescale lectures should include imparting and verification of knowledge beyond factual knowledge, such as skills and competencies (Chiru et al. 2012). This, in turn, calls for the lecturers to offer relevant didactic mechanisms centering the learners, supporting them in their learning process by means of feedback on the individual learning progress and imparting relevant skills and competencies. The use of peer assessment could be one promising possibility to enhance interaction and feedback (Strijbos et al. 2009) and moreover to assess high cognitive levels of educational objectives without massively increasing the workload of lecturers and at the same time, address several skills and competencies (Jaillet 2009).

Typically, verification of knowledge on the high cognitive levels of educational objectives is characterized by assignments which are very complex (e.g., extensive free-text assignments, writing statements, and essays). Consequently, the verification of knowledge of those assignments is time- and resourceconsuming hence impossible to use in a large-scale lecture within the learning process. By using peer assessment, learners evaluate the value or quality of another learner's or group's performance during the learning process (Tahir 2012; Topping 2005) according to specifically defined criteria (Boud and Falchikov 2007). Consequently, peer assessment makes imparting and verification of knowledge concerning the high cognitive levels of educational objectives in large-scale lectures feasible and manageable, since correcting the assignments is no longer the task of the lecturer. However, offline peer assessment requires a lot of coordination efforts by the lecturer, since the individual assessments need to be collected, anonymized and sent out for review to multiple other students. Afterwards, the reviews need to be collected, and the lecturer needs to make sure that every student gets exactly the reviews for his particular assessment. This proceeding is very time-consuming without any resource-saving mechanism (Sung et al. 2005). In contrast the use of information technology (IT) provides various potentials regarding process automation, process tracking, and easy process editing (Davenport 1993). Moreover, the use of IT allows anytime-and-anywhere communication (Gupta and Bostrom 2009) and interactive data can be transferred between learners and lecturers in real-time (Dyson et al. 2009). Van Zundert et al. (2010) point out that there are only a view existing studies concerning an (quasi)experimental setting of peer assessment and that this circumstance prevents specific insights on how peer assessment should be designed. Furthermore, the existing peer assessment literature includes few experimental studies that mainly considered students' perceived learning as an outcome variable rather than examining actual learning effects of peer assessment (Çevik et al. 2015).

Therefore, the research presented here intends to address the shortcomings of a specific design for a peer assessment enabled with IT as well as to support learners during the learning process with assignments addressing the high cognitive levels of educational objectives. To overcome the mentioned challenges, we develop an IT-based peer assessment (ITPA) as a didactical method. The ITPA empowers lecturers teaching large-scale lectures to leverage the potential benefits of peer assessment and at the same time keeps the additional effort for the lecturer at a low level, since most of the back office processes are automated. Therefore, this paper aims to examine the following research questions (RQ):

- RQ 1: How should the ITPA be designed to leverage the potentials of peer assessment while taking into account the limited resources of lecturers?

- RQ 2: Do learners that participated in the ITPA perform better in the final exam-related assignments than those learners who did not participate? 
To achieve our research goal, we follow the design science approach (Hevner et al. 2004; Peffers et al. 2007), particularly the design science research approach by Peffers et al. (2007) (cf. Figure 1). We contribute to an existing body of knowledge with a nascent theory of design and action as an improvement for known problems (Gregor 2006; Gregor and Hevner 2013).

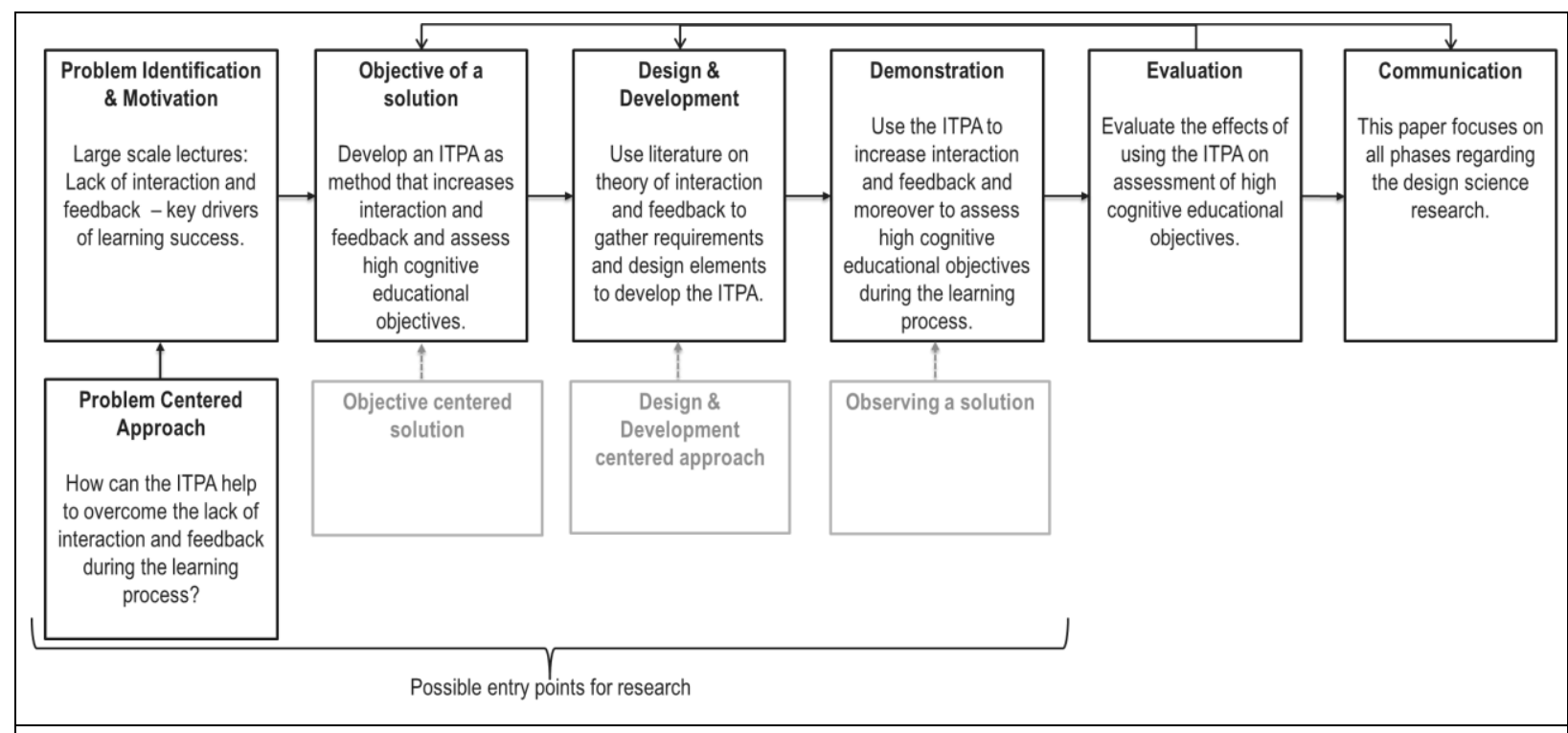

Figure 1. Research Approach for Developing the ITPA. Source: Adopted from Peffers et al. (2007).

We follow the design science research approach, because it is a well-accepted and highly-cited approach in IS research paradigm to construct innovations for utility (Gregor and Hevner 2013; Winter 2008). Moreover, it is a paradigm for the development of technological solutions for given problems (Winter 2010) and helps to create and evaluate successful IT artefacts (Peffers et al. 2007). In our research we want to develop and design the ITPA and subsequently, we want to evaluate the artefact in a real problem situation. Moreover, to ensure that the didactical method ITPA addresses all important types of interaction, we follow Briggs' (2006) theory-driven design approach by grounding our research on theory on interaction and feedback.

In this paper, we present all activities for the development of the ITPA recommended by Peffers et al. (2007). Hence, the structure of the paper mostly reflects the order of the necessary activities. The introduction has addressed the activity problem identification and motivation. To enable a better understanding of the research at hand, section 2 focuses on the theoretical background, the related research results on peer assessment and describes the literature-based IT potentials of peer assessment. Subsequently, we address all remaining activities of the design science research approach. The activity objective of a solution is described in section 3 by identifying requirements from theory. This activity is followed by design and development that addresses the requirements for design elements and specifies how these design elements were integrated into the ITPA (sections 4 and 5). The ITPA was conducted as a quasi-experiment during the learning process with four-week duration and voluntary participation. To use and to comprehensively investigate the ITPA in a real-setting resembles the activities demonstration (section 5) and evaluation (section 6) of Peffers et al.'s (2007) design science research approach. The development of the ITPA is communicated in this paper and hence, corresponds to activity six. In the sections 7 and 8 the relevant results as well as the implications are discussed. Finally, the paper closes with our limitations, a conclusion and an outlook on possible future research. 


\section{Theoretical Foundations}

\section{Peer Assessment in University Teaching}

Peer assessment allows for individual feedback on the learning progress as well as corresponding interventions even in groups with a higher number of learners (Piech et al. 2013). Feedbacks from the peers provide different views that foster students' self-reflection (Leijen et al. 2009). In the course of peer assessment, learners give each other feedback or credit points according to previously defined criteria (Boud and Falchikov 2007). When learners are supposed to provide feedback to other learners, predefined feedback criteria are essential in order to support the feedback provider and to ensure that valuable and constructive feedback is provided (Falchikov and Goldfinch 2000). In the present paper, we use the term of peer assessment to describe learners of a peer group mutually evaluating each other's performances according to defined criteria, while formulating an overall feedback including strengths, weaknesses, and suggestions. The application of peer assessment in university teaching brings about, above all, the following benefits opposed to an evaluation conducted solely by the lecturer:

- Logistically: Lecturers save valuable time if learners give each other feedback and evaluate each other's academic performance (Sadler and Good 2006).

- Pedagogically: The evaluation of responses regarding correctness gives the learner a deeper understanding of the learning contents (Chang et al. 2011). By reading works of others, one can deepen one's own knowledge and develop new ideas and inspiration by evaluating other points of view (Chen 2010; Hovardas et al. 2014; Sadler and Good 2006).

- Metacognitive: Learners will develop awareness for their own strengths and weaknesses (Tahir 2012) and will be able to compare and evaluate their own performance with their peers, at least to a certain extent (Darling-Hammond et al. 1995). Doing so, learners learn to avoid shortcomings (Chang et al. 2012). In addition, learners train their ability to think critically, as well as their evaluation and reflection skills (Jaillet 2009; Leijen et al. 2009; Topping 2005).

- Affectively: Learners perceive qualitative feedback from their peer group as more valuable than a lecturer's grade (Sadler and Good 2006).

The use of peer assessment does not only relieve the lecturer but turns learners into experts themselves. Peer assessment has been widely used in various fields of education, and mostly in higher education (Hsia et al. 2016). Researchers achieve the awareness that students are able to avoid peer pressure by leaving the feedback anonymously (Hsia et al. 2016).

Although peer assessment could bring benefits to students' learning performance (Tseng and Tsai 2007; Tsivitanidou et al. 2011), it comes along with some risks that need to be considered. Jaillet et al. (2009) alert the assessment doing by the peers can pose validity and reliability problems which calls for further investigation. Some studies emphasize learners' anxieties about the fairness and consistency of peer assessment (Cheng and Warren 1997; Rushton 1993). Some authors' investigation indicate that learners with poorer performances might not accept peer feedback as proper (Topping 2005) and might be unwilling to assume any responsibility for assessing their peers, especially in a non-anonymous setting (Falchikov 1995). Moreover, learners could feel overstrained as well as frustrated when facing a complex assessment form, e.g., extensive qualitative feedback (Hovardas et al. 2014). When learners receive poor quality feedback from their peers, it could frustrate them in their learning (Mintzes et al. 2005). These critical facts need to be considered by evaluating and discussing the use of peer assessment.

\section{A Review of Related Work on Peer Assessment Research with IT}

First observations show that peers are indeed able to provide valuable feedback (Dochy et al. 1999; Falchikov and Goldfinch 2000) and that evaluations by the peer group agree with the lecturer's evaluation (Kulkarni et al. 2013). Furthermore, studies indicate that regular feedback given by the peer group has a positive effect on a learner's learning process (Dochy et al. 1999). Depending on the individual design, peer assessment may take place orally or in a written form. Oral peer assessments usually provide face-toface feedback. A written feedback may be paper- or IT-based (cf. (Liu and Sadler 2003)) and can be given anonymously. The use of IT allows for a flexible application. This way, peer assessment can take place synchronously, e.g., by means of chat programs (Sullivan and Pratt 1996), or asynchronously (Tuzi 2004), 
thus providing a benefit in terms of time management. Students can invest the time they need for preparing an assignment or feedback for e.g., self-reflection or evaluation (Veerman et al. 2000). In their study, Liu and Sadler (2003) investigate the use of paper-based peer review with face-to-face meetings in comparison to peer review realized with Microsoft Word and an anonymous online chat for communication. The authors suggest enriching electronic peer reviews with face-to-face interaction. De Raadt et al. (2005) used a peer review within an undergraduate computer course with a self-developed electronic peer reviewing system. Each learner received feedback from the peers on several assignments which was the basis for later lecturer's grading. The used electronic system had been successfully evaluated and considered for wider use (De Raadt et al. 2005). Liang und Tsai (2010) compared a peer assessment with a self and expert assessment, all executed online. The results of their study show that the self-assessment results are not consistent with the results made by the experts. But, peer and expert assessment demonstrate an adequate accordance (Liang and Tsai 2010).

\section{Leveraging the Potentials of Peer Assessment with IT}

Using technology in education not only enables learners to access learning materials regardless of time or space, but also provides lecturers with the opportunity to develop learning activities from new perspectives (Hwang et al. 2014). Moreover, using technology provides potential to integrate innovative learning where large numbers of learners can create and share resources which address the concept of user-generated content (Vom Brocke et al. 2010). Hence, technologies such as learning-management systems as well as mobile devices provide a scaffold to integrate didactic mechanisms in order to improve the interaction between the lecturer and the learners, with the learning content or among the learners themselves. It can also help to enhance the learners' participation, and the quality of teaching (DuncanHowell and Lee 2007). Hence, using IT in peer assessment makes it applicable in large-scale lectures (Bostock 2004). Therefore, it is more suitable for assessing skills and high cognitive levels of educational objectives in large-scale lectures. However, the use of IT in learning can result in frustration, confusion, and reduced learner interest (Hara 2000). Therefore, the learners must be highly self-regulated regarding their own learning since the lecturer can influence the learning process to a small extent only (Butler 2003). Using peer assessment with IT can bring additional problems. Doiron (2003) indicates that using IT in peer assessment demands too much learner effort by putting too much pressure on them, which is not reliable and not necessarily fair. In order not to cognitively overload the learners, we focus on an initial support and scaffold the process.

The widespread use of the IT capabilities following Davenport (1993) forms the basis for the transfer of peer assessment. Davenport and Short (2003) describes the IT capabilities from a process perspective where awareness of IT usage can influence the process design. However, it is useful to think about IT capabilities and their impact in nine different ways which we want to use for the peer assessment. Those capabilities can link directly to the peer assessment, which is based on IT usage in our research. Table 1 shows the IT capabilities based on Davenport (1993) with a short description of them as well as the transfer to the peer assessment. The transfer of the IT capabilities to the peer assessment occurs deductively.

\begin{tabular}{|l|l|l|}
\hline \multicolumn{2}{|c|}{ Table 1. IT Potentials in Peer Assessment. Own Source Based on Davenport (1993). } \\
\hline $\begin{array}{l}\text { IT Capability } \\
\text { (Davenport 1993) }\end{array}$ & Description & Transfer on Peer Assessment \\
\hline Automation & $\begin{array}{l}\text { IT allows replacing or } \\
\text { reducing human labor. }\end{array}$ & $\begin{array}{l}\text { Automatic distribution of learner assignments and } \\
\text { peers' assessments which saves time and costs (Babik } \\
\text { and Ford 2014) and allows for anonymity (Quinn et al. } \\
\text { 2009). }\end{array}$ \\
\hline Informational & $\begin{array}{l}\text { IT provides additional } \\
\text { information. }\end{array}$ & $\begin{array}{l}\text { The system provides e.g., the assessment form with } \\
\text { feedback criteria and updates (e.g., for incoming } \\
\text { deadlines) (Honeychurch et al. 2013). }\end{array}$ \\
\hline Sequential & $\begin{array}{l}\text { IT enables changes in } \\
\text { processing steps. }\end{array}$ & $\begin{array}{l}\text { It is possible to extend deadlines (e.g., for learners' } \\
\text { submission) or to set more feedback loops (Babik and } \\
\text { Ford 2014). }\end{array}$ \\
\hline
\end{tabular}




\begin{tabular}{|l|l|l|}
\hline Tracking & $\begin{array}{l}\text { IT enables detailed } \\
\text { tracking of processing } \\
\text { steps. }\end{array}$ & $\begin{array}{l}\text { The lecturer may monitor submissions and remind } \\
\text { learners of missing submissions. Moreover, they can } \\
\text { control assignment or feedback quality and take } \\
\text { countermeasures if necessary (Honeychurch et al. } \\
\text { 2013). }\end{array}$ \\
\hline Analytical & $\begin{array}{l}\text { IT allows complex } \\
\text { analytical methods for } \\
\text { additional findings. }\end{array}$ & $\begin{array}{l}\text { Diverse data evaluation is possible, e.g., comparison to } \\
\text { best practice after peer assessment (Quinn et al. 20o9) } \\
\text { as well as effects on objective learning outcome (Jaillet } \\
\text { 2009). }\end{array}$ \\
\hline Geographical & $\begin{array}{l}\text { IT enables information } \\
\text { transfer regardless of } \\
\text { geography. }\end{array}$ & $\begin{array}{l}\text { Learners can participate in peer assessment regardless } \\
\text { of time and space. Use of peer assessment in e-learning } \\
\text { scenarios, e.g., MOOCs (massive open online courses) } \\
\text { is possible as well (Kulkarni et al. 2013). }\end{array}$ \\
\hline Integrative & $\begin{array}{l}\text { IT mergers processes or } \\
\text { tasks. }\end{array}$ & $\begin{array}{l}\text { Using IT in peer assessment enables document } \\
\text { management for sharing, storage as well as upload- } \\
\text { /downloading (Brutus and Donia 2010). Moreover, } \\
\text { providing feedback on peers' assignments can be done } \\
\text { directly in the system without the need for uploading } \\
\text { documents (Anson and Goodman 2014). }\end{array}$ \\
\hline Intellectual & $\begin{array}{l}\text { IT gathers and provides } \\
\text { information. }\end{array}$ & $\begin{array}{l}\text { Creating a knowledge base with frequently asked } \\
\text { questions or a forum to discuss the assessment form } \\
\text { (Sitthiworachart and Joy 2004). }\end{array}$ \\
\hline Disintermediating & $\begin{array}{l}\text { Intermediaries are not } \\
\text { useful any longer. }\end{array}$ & $\begin{array}{l}\text { IT simplifies the peer assessment process regarding } \\
\text { document sharing and handling of the information } \\
\text { flow where it reduces complexity (Brutus and Donia } \\
\text { 2010). Printed versions of the peer assignments or } \\
\text { assessments are not necessary any longer. }\end{array}$ \\
\hline
\end{tabular}

\section{Deriving Requirements from Learning Theory of Interaction and Feedback}

Fundamental elements of the individual learning success include the opportunity to receive feedback on one's individual learning progress, to have the possibility of sharing one's opinions concerning the subject matter (Picciano 2002), and to reflect the own knowledge (Gagné et al. 1993). Feedback and interaction during the learning process are regarded as significant predictors in terms of individual learning success (Moore et al. 1996) and positively influence the long-term satisfaction (Alonso et al. 2009). Therefore, we base the derivation of requirements on interaction and feedback as central part for learning.

In the context of interaction, Moore (1989) formulates the most specific differentiation concerning the exchange with learning objects. He differentiates between learner-learner interaction, learner-lecturer interaction as well as learner-content interaction, where all types are presumed to play an important role in education (Bernard et al. 2009; Garrison and Shale 1990). We adopt these three types of interaction for our research and define interaction itself as learning activities, including exchange between learners, lecturers, and content (Schrum and Berge 1997). The interaction between the learners takes place between one learner and others, alone or in group settings, with or without the real-time presence of a lecturer (Moore 1989). The learner-learner interaction is needed both for cognitive purposes and motivational support (Bernard et al. 2009). The interaction among the learners themselves enables social exchange during the learning process (Sims 2003) leading to foster the individual reflection ability (Bandura 1977). In interaction between lecturer and learners, the lecturer should give advice and feedback to learners and need to retain an overview of the learners' performance (Bligh 2000). The lecturer seeks to enhance the learner's interest, including self-direction and self-motivation (Moore 1989). Prior research has shown that learners who interact with their lecturer and their peer are more actively involved in the learning process (Wang et al. 1990) and receive better results in the final exam compared to those who don't interact with others. The learner-content-interaction takes place when learners participate in 
class activities (Thurmond and Wambach 2004) or when they talk to themselves regarding the learning content (Moore 1989). Learners with low or intermediate previous knowledge profit from a high degree of interaction and achieve higher learning results (Snell 1999). An interactive setting can enhances learners' motivation and participation in class, as well as foster learners' exchange (Liu and Sadler 2003; Sims 2003).

Besides interaction, feedback is essential to foster learner's learning process and to demand the application with the learning content (Tahir 2012). The relevance of feedback during the learning process is in line with receiving feedback on one's own performance as well as providing feedback on another learner's performance. When receiving and providing feedback, the improvement of the reflection ability is of great importance (Van Den Boom et al. 2007) as well as the enhancement of self-regulated learning (Ertmer and Newby 1996). Feedback on one's own performance leads to an awareness and understanding of how to control the own learning (Nicol and Macfarlane-Dick 2006).

Thus, it is very relevant to integrate didactic mechanisms in a large-scale lecture and to emphasize learners as a central part of the learning process. The realization of interaction enables receiving and providing feedback. Table 2 presents the general requirements (R) we were able to identify from interaction and feedback in learning. These are the basis for developing the ITPA and this step corresponds to the activity objectives of a solution of Peffers et al.'s (2007) design science research process. The sentence structure of the requirements is based on Hull et al. (2010). For the requirements' formulation the learners' perspective is taken since the learners are the main focus of the ITPA. We base our subsequent design decisions on the constructs linked to our phenomena of interest.

Table 2. Derived Requirements from Theory of Interaction and Feedback. Own Source.

\begin{tabular}{|c|c|}
\hline Requirements & Theoretical Description \\
\hline $\begin{array}{l}\text { R1) Learners should cooperate } \\
\text { together to exchange their } \\
\text { knowledge among each other. }\end{array}$ & $\begin{array}{l}\text { When the learners cooperate with the peers during the learning } \\
\text { process, they can exchange knowledge among each other (Boud et } \\
\text { al. 1999), which enhance motivation (Eisenkopf 2010) and learning } \\
\text { success(Moore and Kearsley 2011). The own learning performance is } \\
\text { enhanced with opportunities for learners to share the own work with } \\
\text { others (Boud 1995). }\end{array}$ \\
\hline $\begin{array}{l}\text { R2) Learners should receive } \\
\text { feedback on the individual } \\
\text { performance. }\end{array}$ & $\begin{array}{l}\text { When the learners receive feedback on their individual performance } \\
\text { during the learning process they can recognize possible } \\
\text { misunderstandings (Hwang et al. 2014). }\end{array}$ \\
\hline $\begin{array}{l}\text { R3) Learners should provide } \\
\text { feedback on an individual } \\
\text { performance. }\end{array}$ & $\begin{array}{l}\text { When the learners provide feedback they can reflect the own } \\
\text { performance and are able to compare and evaluate the performance } \\
\text { with the peers (Darling-Hammond et al. 1995). }\end{array}$ \\
\hline $\begin{array}{l}\text { R4) Learners should have the } \\
\text { possibility to ask questions } \\
\text { regarding unclear points. }\end{array}$ & $\begin{array}{l}\text { In discussions with the lecturer or other learners clarification of } \\
\text { unclear points can clarified and correct interpretation can reinforced } \\
\text { (Thurmond and Wambach 2004; Vonderwell 2003). }\end{array}$ \\
\hline $\begin{array}{l}\text { R5) Learners should be } \\
\text { informed about specific } \\
\text { educational objectives within the } \\
\text { learning content. }\end{array}$ & $\begin{array}{l}\text { The lecturer attempts to achieve teaching aims regarding the } \\
\text { learning content (Moore 1989). When informing the learners } \\
\text { regarding the learning content that addresses diverse cognitive } \\
\text { levels of educational objectives the learners learn the content } \\
\text { comprehensively (Driscoll 2005). }\end{array}$ \\
\hline $\begin{array}{l}\text { R6) Learners should get content } \\
\text { specific assignments in an } \\
\text { activating way. }\end{array}$ & $\begin{array}{l}\text { When learning material is designed in an activating way it supports } \\
\text { social interactions and peer learning activities (Clark and Mayer } \\
\text { 2008). }\end{array}$ \\
\hline $\begin{array}{l}\text { R7) Learners should be able to } \\
\text { reflect and think critically } \\
\text { regarding their solution on an } \\
\text { assignment. }\end{array}$ & $\begin{array}{l}\text { When the learner reflects the own performance and think critically } \\
\text { on the own solution the individual learning process is supported } \\
\text { (Leung et al. 2014). }\end{array}$ \\
\hline
\end{tabular}




\section{Design Elements for the ITPA}

In order to enhance feedback as well as to increase interaction covering all interaction types during the learning process, the integration of didactic mechanisms is needed. For a theory-driven deduction of design elements, we use peer assessment as a theoretical basis (Lehmann and Leimeister 2015). The peer assessment as part of peer learning activates the learners by means of various types of interaction, and supports them via feedback during the learning process. Therefore, from a wording perspective the design elements refer on mechanisms to support the learning process.

Based on the requirements derived from theory of interaction and feedback, we formulate design elements concerning the identified requirements as theoretical foundation for the ITPA (cf. Table 3). The design elements are based on the well-known principles of good practice (Chickering and Gamson 1989). Furthermore, the design elements present the activity design and development of Peffers et al.'s (2007) design science research approach. Following Bitzer et al. (2016) the design elements are created to design the ITPA in a more time-efficient way and to activate the learners in their learning process.

Table 3. Derived Design Elements for the ITPA. Own Source.

\begin{tabular}{|l|l|}
\hline Requirements & Design Elements (D) \\
\hline $\begin{array}{l}\text { R1) Learners should } \\
\text { cooperate together to } \\
\text { exchange their knowledge } \\
\text { among each other. }\end{array}$ & $\begin{array}{l}\text { D1) Each learner will read several solutions on an assignment created } \\
\text { by the peers. Each learner will provide feedback in a written form on } \\
\text { an assignment of several fellow students. The written feedback } \\
\text { contains advices for improvement. The cooperation will be of } \\
\text { asynchronous online characteristic. }\end{array}$ \\
\hline $\begin{array}{l}\text { R2) Learners should receive } \\
\text { feedback on the individual } \\
\text { performance. }\end{array}$ & $\begin{array}{l}\text { D2) Each learner will receive feedback on the own individual solution } \\
\text { to assess the own learning progress. }\end{array}$ \\
\hline $\begin{array}{l}\text { R3) Learners should provide } \\
\text { feedback on an individual } \\
\text { performance. }\end{array}$ & $\begin{array}{l}\text { D3) Each learner will evaluate each other's performances with the help } \\
\text { of specific criteria and a written feedback in an assessment form. }\end{array}$ \\
\hline $\begin{array}{l}\text { R4) Learners should have the } \\
\text { possibility to ask questions } \\
\text { regarding unclear points. }\end{array}$ & $\begin{array}{l}\text { D4) During the lecture, which will be held in presence, the lecturer will } \\
\text { emphasize strengths and weaknesses regarding several solutions. In } \\
\text { discussion the learners can interact with the lecturer and other } \\
\text { learners. }\end{array}$ \\
\hline $\begin{array}{l}\text { R5) Learners should be } \\
\text { informed about specific } \\
\text { educational objectives within } \\
\text { the learning content. }\end{array}$ & $\begin{array}{l}\text { D5) The used assignments will focus on the high cognitive level of } \\
\text { educational objectives and the learners will be informed which specific } \\
\text { educational objectives underlie the assignments. }\end{array}$ \\
\hline $\begin{array}{l}\text { R6) Learners should get } \\
\text { content specific assignments } \\
\text { in an activating way. }\end{array}$ & $\begin{array}{l}\text { D6) The learners will get assignments to foster interaction with the } \\
\text { learning content continuously within the learning process. }\end{array}$ \\
\hline $\begin{array}{l}\text { R7) Learners should be able } \\
\text { to reflect and think critically } \\
\text { regarding their solution on } \\
\text { an assignment. }\end{array}$ & $\begin{array}{l}\text { D7) After creating the solution on an assignment the learners will self- } \\
\text { assess their own solution with several criteria. }\end{array}$ \\
\hline
\end{tabular}

\section{Application of the ITPA in Large-scale Lectures}

\section{Didactic Concept of the Large-scale IS Lecture}

Before presenting the ITPA, we will shortly present the didactic concept of the lecture. The ITPA was implemented in a blended learning introductory IS lecture, designed as a flipped classroom (Lehmann et al. 2015; Oeste et al. 2014). Figure 2 illustrates the collegiate learning process of the relevant lecture. The 
ITPA was applied during Phase 2, namely the peer learning phase, and will be described in detail in the subsection afterwards.

We designed the flipped classroom as a learning cycle, repeating five times during one semester. Each cycle comprises four individual consecutive phases. The first phase can be substituted as self-learn via video- and script-based learning units, as well as additional web-based trainings. The second phase (peer learning) consists of free-text assignments to be solved as individual (where we use the ITPA) or group tasks. The found solutions serve as input for Phase 3, which is held in presence and aims at addressing content-related comprehension questions and ambiguities from the first two phases by means of lecturermoderated discussions. Additionally, the lecturer presents solutions to the free-text assignments and addresses relevant content strengths and weaknesses. During Phase 4, learners attend small lectureaccompanying tutorial groups where they acquire the learning content in small groups.

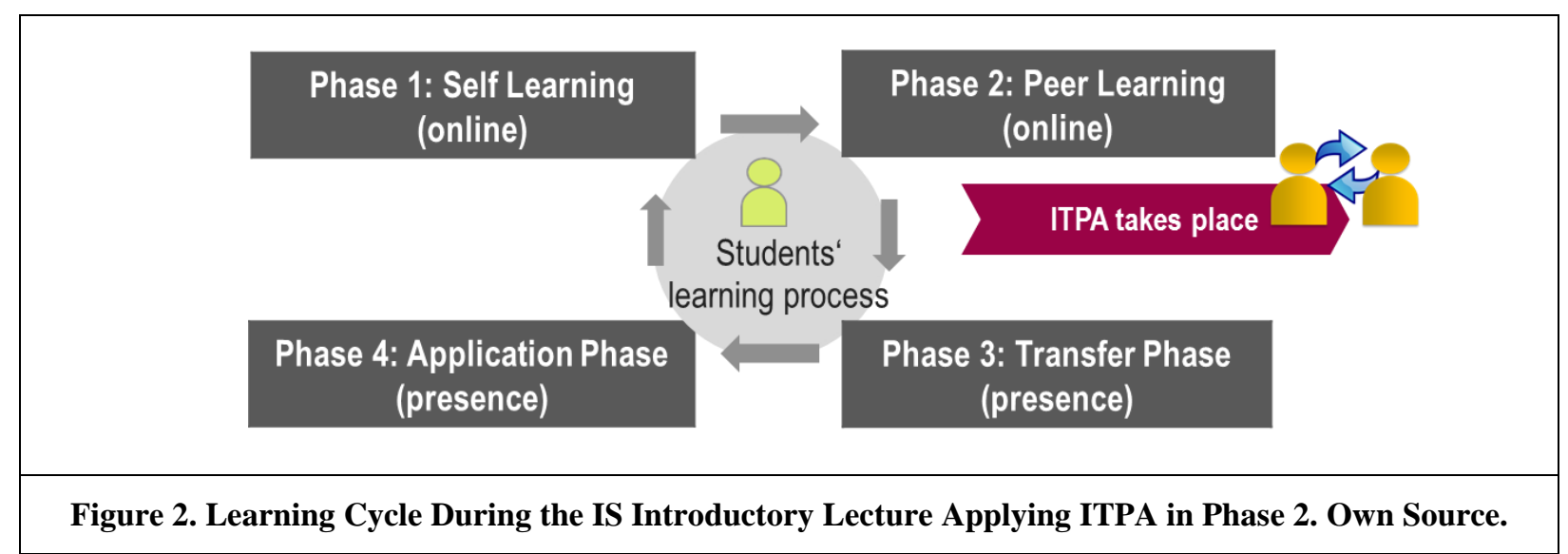

\section{ITPA Design}

The use of the ITPA aims to support the peer learning process by means of receiving and providing feedback, as well as increasing the interaction between learners and the learning content and among the learners themselves. Furthermore, the ITPA means to assess learners' knowledge on high cognitive levels of educational objectives. Hence, learners will receive as well as provide feedback on high cognitive levels of educational objectives. We used the ITPA in a quasi-experimental design once throughout a four-week period during the second phase of the flipped classroom learning process (peer learning phase). Furthermore, the ITPA serves as preparation for Phase 3 for discussions of the solutions (Lehmann and Leimeister 2015).

For IT use, the university's learning management system (LMS) Moodle with the workshop module was used to support the ITPA. Thereby, we used an existing platform and adjusted the settings regarding our needs. A schedule set certain deadlines, with each deadline instructing the learners on what to do in what time frame. Additionally, short videos explained how to use the workshop module in the LMS in order to avoid operational problems. The learners were reminded to solve the remaining task before each deadline.

\section{$1^{\text {st }}$ assignment}

In a first step, the learners received a complex free-text assignment to work on individually in order to interact with the learning content and to create own solutions. Each learner had to solve the free-text assignment individually within one week before uploading it to the LMS, which then automatically distributed the individual solutions to the peers. With the creation of an assignment to interact with the learning content, the design element D6 is implemented. The free-text assignment for the ITPA required depth of content for the solution development, the combining of learning contents, as well as formulating own arguments in the form of a statement. The goal was to address the high levels of educational objectives, in particular analyzing and evaluating, and the learners were informed about these before. Therefore, the design element D5 is implemented. 
The topic of the free-text assignment required the creation of a cost-benefit analysis for a self-chosen example of a business software delivery. Learners were expected to find criteria on their own and to rate and discuss them. In addition, they were supposed to discuss the use of a cost-benefit analysis regarding the software delivery. Each learner had to solve the assignment without including the own full name in the solution to guarantee anonymity. All learners received the same assignment. With the assignment, the learners were supposed to work on final exam-related assignments during the semester. Regarding page limit, the learners received the specification of five typewritten DIN A4 pages in a Word file, Arial font, and front size 11.

\section{1:5 assessment}

In the second phase, each learner received randomly assigned solutions from several fellow students. The ITPA was applied as 1:5 assessment, meaning that each solution was evaluated by five different peers and each learner provided feedback on solutions found by five fellow students. Providing feedback regarding a peers' performance addresses the design element D1. The goal was that each learner's effort to provide feedback remained maintainable while guaranteeing each learner diversified feedback. So far, no relevant research exists concerning the necessary number of peer assessors to ensure valuable and diversified feedback from the peers. The assessment form contained space for a qualitative written feedback and a rating sheet to provide quantitative feedback regarding several criteria. Regarding the written feedback, each feedback provider was supposed to evaluate each solution's strengths and weaknesses and provide suggestions for improvement. The learners were guided with a tutorial about how to provide feedback to their peers. The rating sheet included criteria according to the quality of the solution and the author's knowledge expertise. Additionally, the rating sheet captured criteria for assessing the peers' knowledge at the high cognitive levels of educational objectives. The assessment form for providing feedback implements D3. The assessment was fulfilled anonymously, meaning that no learners were aware whose solution they were assessing. This way, the feedback is more precise, valuable, and honest (Bostock 2004), and a possible feedback manipulation based on social relationships is avoided (Boud and Falchikov 2007), thus allowing for content-based, objective feedback modeling. The provided feedback had to be uploaded to the LMS by a certain deadline.

Moreover, each learner had to reflect on the own performance regarding the solution of the free-text assignment, which address the design element D7. The assessment form for the self-assessment contained the same criteria as the assessment form for the ITPA. Therefore, each learner had to self-assess the own solution regarding quality, knowledge expertise, and attaining the high cognitive levels of educational objectives. The self-assessment of the own learning leads to a greater level of learner independence (Daniel 2001), fosters reflection on the own learning progress (Boud and Falchikov 2007), as well as enhances awareness for the achievements and outcomes of the own learning (Dochy et al. 1999). The selfassessment was realized via an online questionnaire tool. However, the results of the self-assessment of the learners are not mentioned in this research investigation, but since it is part of the design of our ITPA, we mentioned it at this point.

During the assessment phase, the learners interact with the learning content and with each other. The interaction is of asynchronous online characteristic.

\section{$2^{\text {nd }}$ assignment}

In the phase of the second assignment, each learner had to revise their solution accordingly based on the peers' feedback. Hence, each learner received feedback regarding the own performance on the specific free-text assignment and could align the self-assessment with the assessment of the peers. Regarding the received feedback the design element D2 is implemented. This phase occurs online and each learner works individually on the revision of the own solution, which addresses the learner-content interaction. For revision of the solution, each learner had to upload their revised work to the LMS within one week.

\section{Moderated discussion}

During the presence phase, the lecturer presented a set of several solutions of the free-text assignment and emphasized relevant content strengths and weaknesses. Misunderstandings were answered, relevant ambiguities eliminated, and content-specific questions discussed. This increases the interaction between 
the learners and the lecturer as well as among the learners themselves and addresses the design element D4. The lecturer had access to all results via the LMS. After the presence phase, the lecturer uploaded a best-practice solution for the free-text assignment via the LMS. This ensured that each learner was allowed to compare their own solution to the best-practice. Moreover, this enabled each learner to assess their own knowledge regarding the high cognitive levels of educational objectives, thus addressing D2.

The Figure 3 below illustrates the ITPA process regarding the tasks performed by the learners.

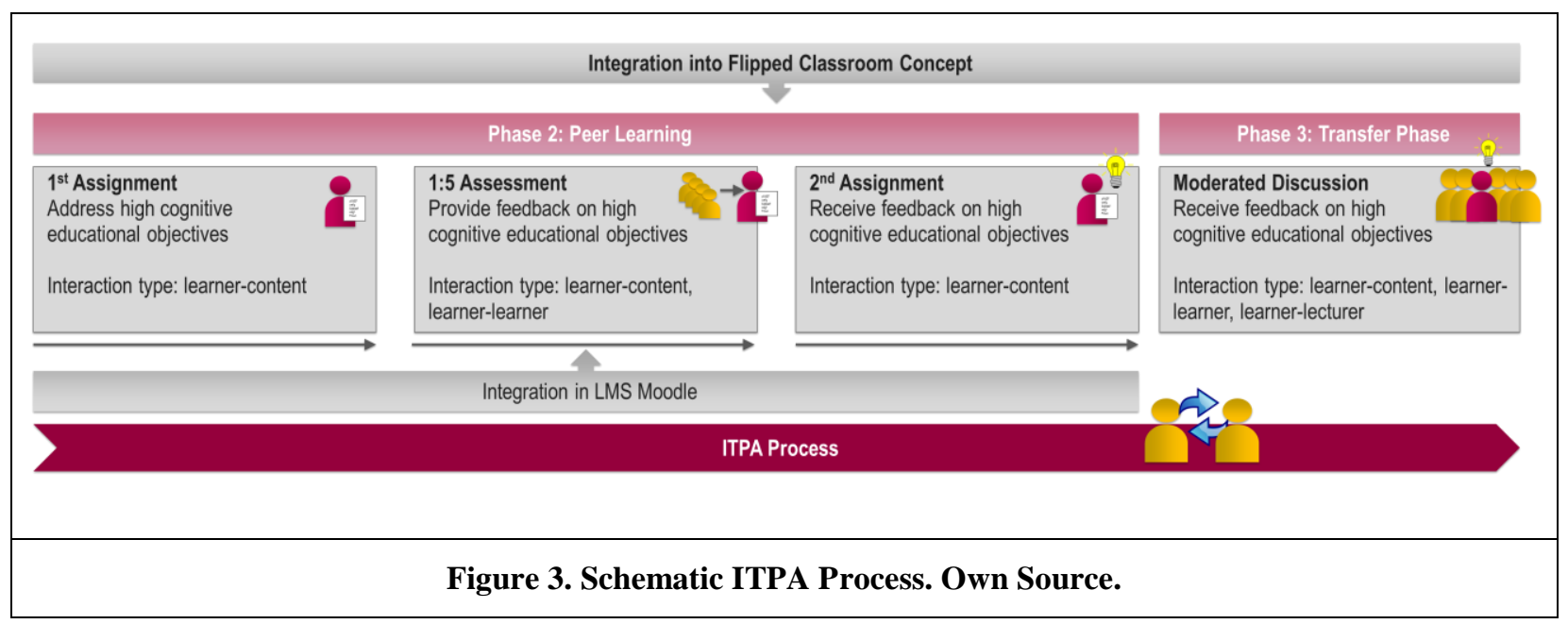

\section{Evaluation Results}

To evaluate the ITPA, we took data from two different semesters but from the same lecture, our IS introductory large-scale lecture for undergraduate students which is held every semester. In the first semester we conducted a pre-test of the ITPA and gathered data regarding utility and intention to use because our research intention was to examine whether the ITPA is ready for being used. In the following semester we started to establish the ITPA in our IS introductory lecture and gathered data to answer research question 2. In both semesters we used the ITPA in the same way. For data analysis, we used SPSS 23. The application of the ITPA in our lecture and the comprehensive evaluation of the ITPA is in line with the demonstration and evaluation phases of Peffers et al.'s (2007) design science research process.

\section{Results Regarding Utility and Intention to Use}

Since the design for the ITPA process is finished, we want to examine the intended (and unintended) impact of the design artefact to show utility and intention to use. This is in line with the design science research approach (Peffers et al. 2007). We conducted a first use of the ITPA in a real setting aiming to examine whether the ITPA is ready for being used in our large-scale lecture. Due to our interest regarding utility and intention to use the ITPA, we focused on constructs from the technology acceptance theory. We decided to keep the items to a minimum, because of the fact that there was no incentive for the students to complete the questionnaire but their goodwill. We used the following constructs: Performance expectancy, effort expectancy, and behavioral intention to use the system. Regarding the measurement of our constructs, we relied on scales provided by previous studies. Attendees of the lecture were around 120 learners. The participation was voluntary. 35 learners took part on the ITPA during the learning process (participation rate 29.2\%). A quantitative evaluation was realized over an online questionnaire including necessary items according to scientific literature. The items were adjusted to relevant research context when necessary. The evaluation was conducted at the end of the ITPA after the phase 3 (transfer phase in presence) was completed. All items were measured using a bipolar 7-point Likert response format with the endpoints labelled as 1 "strongly disagree" to 7 "strongly agree". The results of the evaluation are presented in Table 4. 
Table 4. Pre-test: Evaluation Results Regarding Utility and Intention to Use (N=35).

\begin{tabular}{|l|l|l|l|l|l|}
\hline Constructs & $\begin{array}{l}\text { No. of items } \\
\text { (Reference) }\end{array}$ & Mean & SD & $\begin{array}{l}\text { Cronbach's } \\
\text { Alpha }\end{array}$ & $\mathrm{t}(\mathrm{df})=\mathrm{t}$-value \\
\hline Performance Expectancy & 4 (Venkatesh et al. 2003) & 4.41 & 1.41 & .896 & $\mathrm{t}(33)=1.683^{*}$ \\
\hline Effort Expectancy & 4 (Venkatesh et al. 2003) & 5.94 & 1.17 & .948 & $\mathrm{t}(34)=9.828^{* * *}$ \\
\hline $\begin{array}{l}\text { Behavioral intention to } \\
\text { use the system }\end{array}$ & 3 (Venkatesh et al. 2003) & 5.12 & 1.45 & .888 & $\mathrm{t}(33)=4.521^{* * *}$ \\
\hline
\end{tabular}

The values for Cronbach's Alpha and indicator loadings fulfilled the requested thresholds (Nunnally 2010). Further, the mean values for all constructs are significantly higher than the neutral point of the scale ("neither agree nor disagree"). This indicated high values for performance expectancy, effort expectancy and the behavioral intention to use the system. After the results of the pre-test of the ITPA shows satisfactory results we conclude that our ITPA is ready for being used in our large-scale lecture. For the following semester we started to establish the ITPA in our IS introductory lecture and gathered data to answer the second research question.

\section{Results Regarding Final Exam Performance}

We implemented the ITPA in the subsequent semester than the pre-test of the ITPA was conducted. A total of $\mathrm{N}=129$ learners participated in the ITPA as well as the final exam. The ITPA participation was rewarded with one point extra on top of the final exam scores, which has 90 points in total. Furthermore, we have a sample of 45 learners, who did not take part in the ITPA but, participated in the final exam. The learners who participated in the ITPA belong to the treatment group. The learners who did not participate in the ITPA are the control group sample. Since the ITPA participation was not mandatory, the learners assigned themselves to either treatment or control group. Thus, our research design lacks an important condition for an experimental design, namely the random assignment, and is therefore quasiexperimental (Trochim et al. 2015). We decided to follow this approach since we did not want - and in fact at our university it would also be questionable from a legal point of view - to randomly assign learners to the control group that was supposed to learn less and thus perform worse in the final exam. Especially in educational research studies, random assignment is not possible or practical and hence, quasi-experimental designs are commonly used (Gribbons and Herman 1997).

The focus of this evaluation is to examine whether the ITPA objectively affects the learners' performance. Therefore, we want to investigate whether the learners that participated in the ITPA perform better in related assignments in the final exam than those learners who did not participate. The learning outcome of the related assignments of the final exam allows conclusions for the achieved learning performance.

Before coming up with the examination of research question 2, we compare the sample of treatment and control group. We compare both groups regarding several control variables. These are some descriptive information such as gender, age, and course of study. Moreover, we use the overall self-efficacy for selfregulation as well as technology experience to examine whether the learners differ in both groups. Selfefficacy for self-regulation is an important skill in technology-mediated learning. It means that a learner is focused on tasks, able to reach goals and able to manage their own learning activities (Boekaerts et al. 2005; Franken 2006; Santhanam et al. 2008). Since the ITPA is performed with Moodle, we wanted to know whether the learners differ in their technology experience with Moodle. The control variables gender and course of study are nominally scaled. Therefore, we used the non-parametric chi²-test to examine the difference between both treatment and control group. The chi ${ }^{2}$-test based on Pearson (twodimensional) reveals no significant p-value for gender as well as course of study, meaning that both groups are similar. For the metric data, we tested the standard normal distribution. A KolmogorovSmirnov test reveals that the data are not normally distributed. Thus, we needed to use the MannWhitney U-test to investigate the difference. The Mann-Whitney U-test reveals that the difference of the mean values regarding age is not significant. Hence, both group samples are similar regarding age. Regarding self-efficacy for self-regulation as well as technology experience, the Mann-Whitney U-test reveals that the difference of the mean values is not significant $(\mathrm{p}>.05)$. This also indicates no differences between both groups regarding self-efficacy for self-regulation and technology experience. 
The data collection regarding the demographic information as well as self-efficacy for self-regulation and technology experience took place at the beginning of the semester with an online questionnaire. The items (except the demographic information) were measured using a 7-point Likert scale ranging from 1 "strongly disagree" to 7 "strongly agree". Table 5 shows the results.

\begin{tabular}{|c|c|c|c|c|c|c|c|c|}
\hline \multicolumn{2}{|l|}{ Control Variables } & \multicolumn{3}{|c|}{ Treatment Group } & \multicolumn{3}{|c|}{ Control Group } & \multirow[t]{2}{*}{ p-value } \\
\hline & Sample Size & \multicolumn{3}{|c|}{$\mathrm{N}=129$} & \multicolumn{3}{|c|}{$\mathrm{N}=45$} & \\
\hline \multicolumn{9}{|l|}{ Gender } \\
\hline & male & \multicolumn{3}{|c|}{$44.96 \%(n=58)$} & \multicolumn{3}{|c|}{$53.33 \%(\mathrm{n}=24)$} & \multirow{2}{*}{0.333} \\
\hline & female & \multicolumn{3}{|c|}{$55.04 \%(n=71)$} & \multicolumn{3}{|c|}{$46.67 \%(n=21)$} & \\
\hline \multirow{2}{*}{\multicolumn{2}{|c|}{ Age }} & \multicolumn{2}{|c|}{ Mean } & $\mathrm{SD}$ & \multicolumn{2}{|l|}{ Mean } & $\mathrm{SD}$ & \multirow{2}{*}{0.164} \\
\hline & & \multicolumn{2}{|c|}{23.25 years } & 2.61 & \multicolumn{2}{|c|}{23.78 years } & 2.43 & \\
\hline \multicolumn{9}{|l|}{ Course of Study } \\
\hline \multicolumn{2}{|r|}{ Business Studies } & \multicolumn{3}{|c|}{$96.12 \%(n=124)$} & \multicolumn{3}{|c|}{$93.33 \%(n=42)$} & \multirow{3}{*}{0.442} \\
\hline & Others & \multicolumn{3}{|c|}{$3.88 \%(\mathrm{n}=5)$} & \multicolumn{3}{|c|}{$6.67 \%(n=3)$} & \\
\hline & $\begin{array}{r}\text { Number of Items } \\
\text { (Source) }\end{array}$ & Mean & $\mathrm{SD}$ & $\begin{array}{l}\text { Cronbach's } \\
\text { Alpha }\end{array}$ & Mean & SD & $\begin{array}{l}\text { Cronbach's } \\
\text { Alpha }\end{array}$ & \\
\hline $\begin{array}{l}\text { Self-Efficacy for } \\
\text { Self-Regulation }\end{array}$ & $\begin{array}{l}11 \\
\text { (Santhanam et } \\
\text { al. 2008) }\end{array}$ & 5.48 & 0.81 & .857 & $5 \cdot 35$ & 0.88 & .868 & 0.517 \\
\hline $\begin{array}{l}\text { Technology } \\
\text { Experience }\end{array}$ & $\begin{array}{l}3 \\
\text { (Ball and Levy } \\
\text { 2008) }\end{array}$ & 5.43 & 1.32 & .884 & 5.58 & 1.33 & .855 & 0.447 \\
\hline
\end{tabular}

Based on the results regarding the comparison of treatment and control group, we want to examine research question 2. We do not consider the final grade, but rather the achieved scores in the assignment related to the skills that we intended to train with the ITPA. The final exam consisted of three parts: Part one consisted of single-choice assignments. In the second part, the learners had to answer free-text assignments. In the third part, the learners had to complete data modeling assignments with business process management notation (BPMN). All assignments had to be answered.

Our focus of investigation is on three of the five free-text assignments. With these three free-text assignments the learners were required to create examples and problem cases to discuss specific statements regarding the learning content. Since we especially trained this with the used assignment in the ITPA, we focus on these three free-text assignments (namely A1, A3, and A4). With the three free-text assignments focusing on the requirements, the learners could have achieved 20.5 points. With the freetext assignments that did not focused on the requirements, the learners could have achieved 13.5 points (namely A2, and A5).

To answer our research question, our hypotheses are as follows:

- Ho: Learners participating in the ITPA do not perform better in related free-text assignments in the final exam than those learners who did not participate.

- H1: Learners participating in the ITPA do perform better in related free-text assignments in the final exam than those learners who did not participate.

For a meaningful statistical evaluation whether both groups differ in their achieved points in the final exam-related assignment, we used a t-test for independent samples. 
Table 6. Comparing Treatment and Control Group Regarding Learning Performance.

\begin{tabular}{|c|c|c|c|}
\hline Variables & Treatment Group & Control Group & $t(d f)=t-v a l u e$ \\
\hline Sample Size & $\mathrm{N}=129$ & $\mathrm{~N}=45$ & \\
\hline $\begin{array}{l}\text { Part 1: } \\
\text { Single-choice assignments } \\
\text { (max. 10 points) }\end{array}$ & $\begin{array}{l}\text { Mean }=5.47 \\
\mathrm{SD}=1.66\end{array}$ & $\begin{array}{l}\text { Mean }=5.36 \\
\mathrm{SD}=2.02\end{array}$ & $\mathrm{t}(172)=.384$ \\
\hline $\begin{array}{l}\text { Part 2: } \\
\text { Non peer-assessment related } \\
\text { free-text assignments }\left(A 2, A_{5}\right) \\
\text { (max. 13.5 points) }\end{array}$ & $\begin{array}{l}\text { Mean }=4.42 \\
\mathrm{SD}=3.26\end{array}$ & $\begin{array}{l}\text { Mean }=3.98 \\
\mathrm{SD}=3.46\end{array}$ & $\mathrm{t}(172)=.779$ \\
\hline $\begin{array}{l}\text { Peer-assessment related } \\
\text { free-text assignments }(A 1, A 3, A 4) \\
\text { (max. 20.5 points) }\end{array}$ & $\begin{array}{l}\text { Mean }=7.35 \\
\mathrm{SD}=3.85\end{array}$ & $\begin{array}{l}\text { Mean }=6.15 \\
\mathrm{SD}=3.49\end{array}$ & $\mathrm{t}(172)=1.844^{*}$ \\
\hline $\begin{array}{l}\text { Part 3: } \\
\text { BPMN assignments } \\
\text { (max. } 46 \text { points) }\end{array}$ & $\begin{array}{l}\text { Mean }=23.39 \\
\mathrm{SD}=5 \cdot 74\end{array}$ & $\begin{array}{l}\text { Mean }=22.42 \\
\mathrm{SD}=6.46\end{array}$ & $t(172)=.951$ \\
\hline
\end{tabular}

Table 6 shows the results that the learners achieved in the final exam: the results of the single-choice assignments, the free-text assignments, and the modeling assignments. The t-test for independent samples reveals that both groups are similar in the mean values of single-choice and modeling assignments. Moreover, the result of the t-test shows that both groups are almost similar in the mean values regarding the free-text assignments A2 and A5. The result of the difference of the mean values achieved in the three free-text assignments (namely A1, A3, and A4) is significant at p <.05. Learners of the treatment group achieved a mean score of 7.35 corresponding to the maximum points of 20.5. In contrast, the learners of the control group achieved significantly less points. Thus, the alternative hypothesis (H1) can be confirmed which means that learners participating in the ITPA do perform better in related assignments in the final exam than those learners who do not participate.

\section{Discussion}

Although the use of peer assessment is not new in education, there is still a lack in research studies using peer assessment in an experimental or quasi-experimental setting by examining its actual learning effects (Van Zundert et al. 2010). Therefore, we created the ITPA and focused in our data analysis how learners perceive its utility and intention to use, and whether the learners that participated in the ITPA perform better in final exam-related assignments than those learners who did not participate.

Our results regarding research question 2 show that both treatment and control group are similar regarding several control variables (cf. Table 5). Table 6 shows that the learners who participated in the ITPA achieve better results in the three free-text assignments. Thus, the learners' performance is significantly higher regarding the three free-text assignments. These three free-text assignments were similar to the structure of the assignment used in the ITPA and required the learners for discussing and for creating examples and problem cases regarding specific learning content. Moreover, the results show that both groups are similar in their performance regarding the single-choice, the modeling assignments, and the free-text assignments A2 and A5. This is an indication that the sample differences in the free-text assignments $\mathrm{A} 1, \mathrm{~A}_{3}$, and $\mathrm{A} 4$ are a result of the ITPA used during the learning process.

We need to consider that the difference of the mean values in the three free-text assignments in both groups is present although not very high. In our lecture we made the experience that the learners have difficulties in answering free-text assignments, which gave us the intention to create the ITPA. However, we assume using the ITPA only once is too less. By conducting the ITPA more often during the learning process, we assume to expect stronger results. We intended to train the learners in answering complex free-text assignments and the results show a significant result. Of course, the free-text assignments in the final exam were not of subject of the assignment used in the ITPA. 
The results of the mean values regarding single-choice and modeling assignments are much higher compared to the mean values of the free-text assignments. An explanation could be that during the learning process the learners have much more opportunities in training their knowledge regarding singlechoice and modeling assignments. This is realized over E-Assessments via Moodle (that cover knowledge on the cognitive levels of remembering and understanding) and modeling assignments (that are trained in small lecture-accompanying tutorial groups that cover the cognitive level applying). These assignments are less complex than the free-text assignments.

Participating in the ITPA reveals an increase in dealing with the learning content as well as providing individual feedback on content-based strengths and weaknesses. Thereby, learners are supported during their learning process. Dealing with the learning content during the learning process leads to higher learning success and is in line with previous research results (Birenbaum and Dochy 1995; Chou 2002). Since both groups show similar results regarding their technology experience (cf. Table 5) it cannot be state that only learners who have more technology experience with Moodle participated in the ITPA. Moreover, the learners are similar regarding self-efficacy for self-regulation, which means that the learners are able to manage their own learning activities. Since the ITPA was conducted individually outside class, it is important that learners can focus on their task and show high self-regulation. However, we cannot state that only learners who show a higher degree in self-efficacy for self-regulation participated in the ITPA, since the results in both groups are equal. We are not able to show the motivation of the learners regarding the treatment and control group sample. Therefore, we have to take into consideration that possibly only learners who show a higher degree in motivation participated in the ITPA and hence performed better in related assignments in the final exam.

However, our results show that the ITPA constitutes a possibility to integrate complex free-text assignments into the learning process of a large-scale lecture. Additionally, ITPA is a useful didactical method for our flipped classroom concept, structuring the peer learning phase as well as providing valuable input for the presence phase and moderated discussion.

\section{Implications for Theory and Practice}

For the theoretical implication, the study contributes to the involvement as well as the emphasis of the role of peers in the learning process. The learners adopt the lecturer's role and assess their peers, which enables reflection and metacognition. Thus, the results contribute to the didactical theories of IS research by providing insights on a learner-centered approach. Moreover, the study underlines the pedagogical research regarding imparting and verification of knowledge on the high cognitive levels of educational objectives in large-scale lectures at an undergraduate level. This enables a complex and comprehensive understanding of the learning content beyond the factual knowledge and promotes skills in critical thinking and problem solving. The results can also be applied to other teaching-learning environments. Peer assessment is a valuable and enhancing didactical method not only for university large-scale lectures, but also for e-learning lectures (e.g., MOOCs) or traditional teaching-learning environments or other new contexts of interest.

The results of this paper are of practical relevance for researchers, lecturers, and practitioners alike, since they illustrate a way to use ITPA to address learning, interaction, and feedback in a large-scale lecture. Our study reveals a way to engage and activate learners in large-scale lectures in spite of limited resources. The results antagonize the challenges of large-scale lectures. Regarding the assignment used for the ITPA, comprehension questions can be clarified and complex issues of the learning content can be discussed. Moreover, by using the ITPA the learners are required to deal with IT and digital media that train their competence in IT use. Therefore, the learner-lecturer interaction is limited to the presence phase, which complies with the lecturer's limited resources and does not additionally increase their workload.

\section{Limitations, Future Research, and Conclusion}

Any findings or implications of this study need to be considered in light of its limitations. Since we gathered our data in a real setting without random assignment to treatment or control group, we cannot precisely prove that an increase in learning performance will solely result from learner participation in the ITPA during the learning process. We did not have the possibility to assign the learners randomly to 
either the treatment or control group because of the disadvantage for the learners in the control group. We cannot realize such a research design due to legal regulations, since even randomly assigning learners to a treatment that is supposed to result in a lower learning success (our control group) could lead to lawsuits against the university, and as a consequence, the annulment of the final exam. However, this might be different in other countries for example. We need to take into consideration that the results would be more convincing with a research study of a true experimental design.

As is typical for quasi-experimental studies, our research study may have been confronted with threats to its internal validity (Erez et al. 2002). A quasi-experimental design is subject to several confounders, meaning that changes in learning success could also arise from other external effects not connected to the ITPA participation (Coolican 2014). As a result, another limitation of our research methodology is the self-selection bias (Gautier and Klaauw 2012) because the learners assigned themselves to the treatment group with their voluntary decision that is typically for quasi-experimental designs. Thus, it might be possible that learners who are either highly motivated or interested in new learning scenarios participated in the ITPA and hence achieved better learning results in the final exam. However, we demonstrate that both the treatment and control group are very similar, for example regarding their self-efficacy for selfregulation (cf. Table 5), which states that the learners are able to autonomously control their own learning. We cannot prove that both groups are similar, but we have strong empirical indications that both groups are comparable and that the differences in their performance in the final exam can be related to the participation in the ITPA. Nevertheless, future research should exclude self-selection bias by randomly assigning students to treatment or control group. This could be realized by supporting the control group with a teacher assessment, for example, to treat everyone equally and for reason of fairness.

In our research approach, the sample sizes differ greatly, which presents another limitation of our research and the discussion of the results. Another fact that limits our study is that it is cross-sectional rather that longitudinal. This limits the strength of causal inferences. To exclude this limitation, an option could be to repeat the ITPA more often during the learning process of one semester. Before and after the ITPA, a knowledge test could be conducted in order to analyze the knowledge acquisition and draw conclusions about the influence of the ITPA on attaining knowledge by using it.

The ITPA will be established in our didactic concept of the IS introductory lecture. One change we will undertake is the frequency of the ITPA. Currently, we used the ITPA once in our lecture. The idea is to repeat the ITPA process several times during a lecture. Research investigation will then focus on the alteration in the individual learning process, knowledge acquisition regarding learning success, as well as skill development such as reflection ability, critical thinking, meta-cognition, and complex problem solving. Since our research focuses on verifying high cognitive levels of educational objectives in largescale lectures, we intend to investigate the factual resource consumption by using the ITPA. Moreover, future research will determine how many peer assessors are needed to ensure high-quality and diversified feedback. There are studies comparing peer versus lecturer feedback (Jaillet 2009; Van Zundert et al. 2010), but no scientific insights on how many assessors are sufficient. 


\section{Acknowledgements}

The results presented in this article were partly developed in the research project StaySmart ("Age-diverse employees-tandems for mobile and context-sensitive competence management using the example of smart technology") which is funded by the German Federal Ministry of Education and Research (FKZ: 01FK14008). The responsibility for the content of this publication lies with the authors.

\section{References}

Alonso, F., Manrique, D., and Viñes, J. M. 2009. "A moderate constructivist e-learning instructional model evaluated on computer specialists," Computers \& Education (53:1), pp. 57-65.

Anderson, L., Krathwohl, D., Airasian, P. W., Cruikshank, K. A., Mayer, R. E., Pintrich, P., and Wittrock, J. 2001. A Taxonomy for Learning, Teaching, and Assessing: A Revision of Bloom's Taxonomy of Educational Objectives Addison Wesley Longmann, New York.

Anson, R., and Goodman, J. A. 2014. "A Peer Assessment System to Improve Student Team Experiences," Journal of Education for Business (89:1), pp. 27-34.

Babik, D., and Ford, E. 2014. "Co-Creation and Iterative Social Learning in Technology-Enabled Peer Assessment Environment (Double-Loop Mutual Assessment Approach)," Proceedings of the Twentieth Americas Conference on Information Systems, Savannah, USA

Ball, D. M., and Levy, Y. 2008. "Emerging educational technology: Assessing the factors that influence instructors' acceptance in information systems and other classrooms," Journal of Information Systems Education (19:4), pp. 431-444.

Bandura, A. 1977. Social Learning Theory Prentice-Hall, Englewood Cliffs, NJ.

Bernard, R. M., Abrami, P. C., Borokhovski, E., Wade, C. A., Tamim, R. M., Surkes, M. A., and Bethel, E. C. 2009. "A meta-analysis of three types of interaction treatments in distance education," Review of Educational Research (79:3), pp. 1243-1289.

Birenbaum, M., and Dochy, F. J. 1995. Alternatives in assessment of achievements, learning processes and prior knowledge Springer Science \& Business Media, New York.

Bitzer, P., Söllner, M., and Leimeister, J. M. 2016. "Design Principles for High-Performance Blended Learning Services Delivery - The Case of Software Trainings in Germany," Business \& Information Systems Engineering (BISE) (58:2), pp. 135-149.

Bligh, D. 2000. What's the use of lectures? Jossey-Bass Publisher, San Francisco.

Bloom, B. S., and Krathwohl, D. R. 1956. Taxonomy of educational objectives. The classification of educational goals, by a committee of college and university examiners. Handbook I, Cognitive domain Green Longmans New York.

Boekaerts, M., Pintrich, P. R., and Zeidner, M. 2005. Handbook of self-regulation Elsevier Academic Press, Burlington, MA.

Bostock, S. J. 2004. "Motivation and electronic assessment," Effective Learning and Teaching in Computing, pp. 86-99.

Boud, D. 1995. Enhancing Learning Through Self-Assessment. London. Routledge Routledge, London.

Boud, D., Cohen, R., and Sampson, J. 1999. "Peer learning and assessment," Assessment \& evaluation in higher education (24:4), pp. 413-426.

Boud, D., and Falchikov, N. 2007. Rethinking assessment in higher education: Learning for the longer term Routledge, Abingdon, Oxon.

Briggs, R. O. 2006. "On theory-driven design and deployment of collaboration systems," International Journal of Human-Computer Studies (64:7), pp. 573-582.

Brutus, S., and Donia, M. B. 2010. "Improving the effectiveness of students in groups with a centralized peer evaluation system," Academy of Management Learning \& Education (9:4), pp. 652-662.

Butler, D. L. 2003. "Structuring instruction to promote self-regulated learning by adolescents and adults with learning disabilities," Exceptionality (11:1), pp. 39-60.

Çevik, Y. D., Haşlaman, T., and Çelik, S. 2015. "The effect of peer assessment on problem solving skills of prospective teachers supported by online learning activities," Studies in Educational Evaluation (44, pp. 23-35.

Chang, C.-C., Tseng, K.-H., Chou, P.-N., and Chen, Y.-H. 2011. "Reliability and validity of Web-based portfolio peer assessment: A case study for a senior high school's students taking computer course," Computers \& Education (57:1), pp. 1306-1316. 
Chang, C.-C., Tseng, K.-H., and Lou, S.-J. 2012. "A comparative analysis of the consistency and difference among teacher-assessment, student self-assessment and peer-assessment in a Web-based portfolio assessment environment for high school students," Computers \& Education (58:1), pp. 303-320.

Chen, C.-h. 2010. "The implementation and evaluation of a mobile self-and peer-assessment system," Computers \& Education (55:1), pp. 229-236.

Cheng, W., and Warren, M. 1997. "Having second thoughts: student perceptions before and after a peer assessment exercise," Studies in Higher Education (22:2), pp. 233-239.

Chickering, A. W., and Gamson, Z. F. 1989. "Seven principles for good practice in undergraduate education," Biochemical Education (17:3), pp. 140-141.

Chiru, C., Ciuchete, S. G., Lefter, G. G., and Paduretu, E. 2012. "A Cross Country Study on University Graduates Key Competencies. An Employer's Perspective," Procedia - Social and Behavioral Sciences (46:0), pp. 4258-4262.

Chou, C. C. 2002. "A comparative content analysis of student interaction in synchronous and asynchronous learning networks," System Sciences, 2002. HICSS. Proceedings of the 35th Annual Hawaii International Conference on, IEEE, pp. 1795-1803.

Clark, R. C., and Mayer, R. E. 2008. "Learning by viewing versus learning by doing: Evidence-based guidelines for principled learning environments," Performance Improvement (47:9), pp. 5-13.

Coolican, H. 2014. Research methods and statistics in psychology, (6th edition ed.) Psychology Press, New York, NY.

Daniel, R. 2001. "Self-assessment in performance," British Journal of Music Education (18:03), pp. 215226.

Darling-Hammond, L., Ancess, J., and Falk, B. 1995. Authentic assessment in action: Studies of schools and students at work Teachers College Press.

Davenport, T. H. 1993. Process innovation: reengineering work through information technology Harvard Business School Press, Boston, Massachusetts

Davenport, T. H., and Short, J. 2003. "The new industrial engineering: Information technology and business process redesign," in: Operations management: critical perspectives on business and management, M. Lewis and N. Slack (eds.), Routledge, London, UK, 2003, pp. 61-118.

De Raadt, M., Toleman, M., and Watson, R. 2005. "Electronic peer review: A large cohort teaching themselves? ," Proceedings ASCILITE, Brisbane, Australia.

Dochy, F., Segers, M., and Sluijsmans, D. 1999. "The use of self-, peer and co-assessment in higher education: A review," Studies in Higher Education (24:3), pp. 331-350.

Doiron, G. 2003. "The value of online student peer review, evaluation and feedback in higher education," CDTL Brief (6:9), pp. 1-2.

Driscoll, M. P. 2005. "Gagné's Theory of Instruction," in: Psychology of learning for instruction, M.P. Driscoll (ed.), Pearson Allyn and Bacon, Bosten 2005.

Duncan-Howell, J. A., and Lee, K.-T. 2007. "M-Learning-Innovations and Initiatives: Finding a place for mobile technologies within tertiary educational settings," Ascilite 2007, Singapore.

Dyson, L. E., Litchfield, A., Raban, R., and Tyler, J. 2009. "Interactive classroom mLearning and the experiential transactions between students and lecturer," Ascilite.

Ebert-May, D., Brewer, C., and Allred, S. 1997. "Innovation in large lectures: Teaching for active learning," Bioscience, pp. 601-607.

Eisenkopf, G. 2010. "Peer effects, motivation, and learning," Economics of Education Review (29:3), pp. 364-374.

Erez, A., Lepine, J. A., and Elms, H. 2002. "Effects of rotated leadership and peer evaluation on the functioning and effectiveness of self-managed teams: a quasi-experiment," Personnel Psychology (55:4), pp. 929-948.

Ertmer, P. A., and Newby, T. J. 1996. "The expert learner: Strategic, self-regulated, and reflective," Instructional science (24:1), pp. 1-24.

Falchikov, N. 1995. "Peer feedback marking: developing peer assessment," Programmed Learning (32:2), pp. $175-187$.

Falchikov, N., and Goldfinch, J. 2000. "Student Peer Assessment in Higher Education: A Meta-Analysis Comparing Peer and Teacher Marks," Review of Educational Research (70:3), pp. 287-322.

Fortes, P. C., and Tchantchane, A. 2010. "Dealing with Large Classes: A Real Challenge," Procedia - Social and Behavioral Sciences (8:0), pp. 272-280.

Franken, R. 2006. Human motivation, (6th ed.) Wadsworth, Florence, KY. 
Gagné, E. D., Yekovich, C. W., and Yekovich, F. R. 1993. The cognitive psychology of school learning HarperCollins College, New York.

Garrison, D. R., and Shale, D. 1990. "A new framework and perspective," in: Education at a distance: From issues to practice, D.R. Garrison and D. Shale (eds.), RE Krieger Publishing Company, Malabar, FL, 1990, pp. 123-133.

Gautier, P. A., and Klaauw, B. v. d. 2012. "Selection in a field experiment with voluntary participation," Journal of Applied Econometrics (27:1), pp. 63-84.

Gregor, S. 2006. "The nature of theory in information systems," MIS Quarterly, pp. 611-642.

Gregor, S., and Hevner, A. R. 2013. "Positioning and presenting design science research for maximum impact," MIS Quarterly (37:2), pp. 337-356.

Gribbons, B., and Herman, J. 1997. "True and quasi-experimental designs," Practical Assessment, Research \& Evaluation (5:4).

Gupta, S., and Bostrom, R. G. 2009. "Technology-Mediated Learning: A Comprehensive Theoretical Model," Journal of the Association for Information Systems (10:9).

Hagstrom, F. 2006. "Formative learning and assessment," Communication Disorders Quarterly (28:1), pp. 24-36.

Hara, N. 2000. "Student distress in a web-based distance education course," Information, Communication \& Society (3:4), pp. 557-579.

Hevner, A. R., March, S. T., Park, J., and Ram, S. 2004. "Design science in information systems research," MIS Quarterly (28:1), pp. 75-105.

Honeychurch, S., Barr, N., Brown, C., and Hamer, J. 2013. "Peer assessment assisted by technology," International Journal of e-Assessment (3:1).

Hovardas, T., Tsivitanidou, O. E., and Zacharia, Z. C. 2014. "Peer versus expert feedback: An investigation of the quality of peer feedback among secondary school students," Computers \& Education (71, pp. $133-152$.

Hsia, L.-H., Huang, I., and Hwang, G.-J. 2016. "Effects of Different Online Peer-Feedback Approaches on Students' Performance Skills, Motivation and Self-Efficacy in a Dance Course," Computers \& Education.

Hull, E., Jackson, K., and Dick, J. 2010. Requirements engineering Springer Science \& Business Media.

Hwang, G.-J., Hung, C.-M., and Chen, N.-S. 2014. "Improving learning achievements, motivations and problem-solving skills through a peer assessment-based game development approach," Educational Technology Research and Development (62:2), pp. 129-145.

Jaillet, A. 2009. "Can Online Peer Assessment Be Trusted?," Educational Technology \& Society (12:4), pp. 257-268.

Johnson, L., Adams S., Cummins, M., Estrada, V., Freeman, A., and Hall, C. 2016. NMC Horizon Report: 2016 Higher Education Edition The New Media Consortium., Austin, Texas.

Kulkarni, C., Wei, K. P., Le, H., Chia, D., Papadopoulos, K., Cheng, J., Koller, D., and Klemmer, S. R. 2013. "Peer and self assessment in massive online classes," ACM Transactions on Computer-Human Interaction (20:6), p 33.

Lehmann, K., and Leimeister, J.-M. 2015. "Theory-driven Design of an IT-based Peer Assessment to Assess High Cognitive Levels of Educational Objectives in Large-scale Learning Services," 23rd European Conference on Information Systems (ECIS 2015), Münster, Germany.

Lehmann, K., Oeste, S., Janson, A., Söllner, M., and Leimeister, J. M. 2015. "Flipping the Classroom - ITunterstützte Lerneraktivierung zur Verbesserung des Lernerfolges einer universitären Massenlehrveranstaltung," HMD Praxis der Wirtschaftsinformatik (52:1), 2014/12/24, pp. 81-95.

Leijen, Ä., Lam, I., Wildschut, L., Simons, P. R.-J., and Admiraal, W. 2009. "Streaming video to enhance students' reflection in dance education," Computers \& Education (52:1), pp. 169-176.

Leung, K.-C., Leung, F. K. S., and Zuo, H. 2014. "A study of the alignment of learning targets and assessment to generic skills in the new senior secondary mathematics curriculum in Hong Kong," Studies in Educational Evaluation (43:0), pp. 115-132.

Liang, J.-C., and Tsai, C.-C. 2010. "Learning through science writing via online peer assessment in a college biology course," The Internet and Higher Education (13:4), pp. 242-247.

Liu, J., and Sadler, R. W. 2003. "The effect and affect of peer review in electronic versus traditional modes on L2 writing," Journal of English for Academic Purposes (2:3), pp. 193-227.

Mintzes, J. J., Wandersee, J. H., and Novak, J. D. 2005. Assessing science understanding: A human constructivist view Academic Press. 
Moore, A., Masterson, J. T., Christophel, D. M., and Shea, K. A. 1996. "College Teacher Immediacy and Student Ratings of Instruction," Communication Education (45:1), pp. 29-39.

Moore, M. G. 1989. "Three types of interaction.," The American Journal of Distance Education (3:2), pp. $1-6$.

Moore, M. G., and Kearsley, G. 2011. Distance education: A systems view of online learning Wadsworth Publishing Company, Belmont, California.

Nicol, D. J., and Macfarlane-Dick, D. 2006. "Formative assessment and self-regulated learning: a model and seven principles of good feedback practice," Studies in Higher education (31:2), 2006/04/o1, pp. 199-218.

Nunnally, J. C. 2010. Psychometric Theory $3 E$ Tata McGraw-Hill Education, New York.

Oeste, S., Lehmann, K., Janson, A., and Leimeister, J. M. 2014. "Flipping the IS Classroom - TheoryDriven Design for Large-Scale Lectures," International Conference on Information Systems (ICIS), Auckland, New Zealand.

Peffers, K., Tuunanen, T., Rothenberger, M. A., and Chatterjee, S. 2007. "A design science research methodology for information systems research," Journal of Management Information Systems (24:3), pp. 45-77.

Picciano, A. G. 2002. "Beyond student perceptions: Issues of interaction, presence, and performance in an online course," Journal of Asynchronous learning networks (6:1), pp. 21-40.

Piech, C., Huang, J., Chen, Z., Do, C., Ng, A., and Koller, D. 2013. "Tuned models of peer assessment in MOOCs," arXiv preprint arXiv:1307.2579.

Quinn, D., Shurville, S., Willey, K., and Gardner, A. 2009. "Improving self- and peer assessment processes with technology," Campus-Wide Information Systems (26:5), pp. 379-399.

Rushton, C. 1993. "Peer Assessment in a Collaborative Hypermedia Environment: A Case Study," Journal of Computer-Based Instruction (20:3), pp. 75-80.

Sadler, P. M., and Good, E. 2006. "The impact of self-and peer-grading on student learning," Educational Assessment (11:1), pp. 1-31.

Santhanam, R., Sasidharan, S., and Webster, J. 2008. "Using self-regulatory learning to enhance elearning-based information technology training," Information Systems Research (19:1), pp. 26-47.

Schrum, L., and Berge, Z. L. 1997. "Creating Student Interaction within the Educational Experience: A Challenge for Online Teachers," Canadian Journal of Educational Communication (26:3), pp. 133144 .

Schwab, K., and Samans, R. 2016. "The Future of Jobs. Employment, Skills and Workforce Strategy for the Fourth Industrial Revolution," World Economic Forum.

Sims, R. 2003. "Promises of interactivity: Aligning learner perceptions and expectations with strategies for flexible and online learning," Distance Education (24:1), pp. 87-103.

Sitthiworachart, J., and Joy, M. 2004. "Web-based peer assessment system with an anonymous communication tool," Proceedings of the IEEE International Conference on Advanced Learning Technologies, Joensuu, Finland.

Snell, Y. S., Linda S 1999. "Interactive lecturing: strategies for increasing participation in large group presentations," Medical Teacher (21:1), pp. 37-42.

Strijbos, J.-W., Ochoa, T. A., Sluijsmans, D. M., Segers, M. S., and Tillema, H. H. 2009. "Fostering interactivity through formative peer assessment in (web-based) collaborative learning environments," Cognitive and emotional processes in web-based education: Integrating human factors and personalization, pp. 375-395.

Sullivan, N., and Pratt, E. 1996. "A comparative study of two ESL writing environments: A computerassisted classroom and a traditional oral classroom," System (24:4), pp. 491-501.

Sung, Y.-T., Chang, K.-E., Chiou, S.-K., and Hou, H.-T. 2005. "The design and application of a web-based self- and peer-assessment system," Computers \& Education (45:2), pp. 187-202.

Tahir, I. H. 2012. "A Study on Peer Evaluation and Its Influence on College ESL Students," Procedia Social and Behavioral Sciences (68:0), pp. 192-201.

Thurmond, V., and Wambach, K. 2004. "Understanding interactions in distance education: A review of the literature," International Journal of Instructional Technology and Distance Learning (1:1), pp. 926.

Topping, K. J. 2005. "Trends in peer learning," Educational psychology (25:6), pp. 631-645.

Trochim, W., Donnelly, J. P., and Arora, K. 2015. Research methods: The essential knowledge base Nelson Education, Boston, MA. 
Tseng, S.-C., and Tsai, C.-C. 2007. "Online peer assessment and the role of the peer feedback: A study of high school computer course," Computers \& Education (49:4), pp. 1161-1174.

Tsivitanidou, O. E., Zacharia, Z. C., and Hovardas, T. 2011. "Investigating secondary school students' unmediated peer assessment skills," Learning and Instruction (21:4), pp. 506-519.

Tuzi, F. 2004. "The impact of e-feedback on the revisions of L2 writers in an academic writing course," Computers and Composition (21:2), pp. 217-235.

Van De Grift, T., Wolfman, S. A., Yasuhara, K., and Anderson, R. J. 2002. "Promoting interaction in large classes with a computer-mediated feedback system," Washington State University, pp. 1-10.

Van Den Boom, G., Paas, F., and van Merriënboer, J. J. 2007. "Effects of elicited reflections combined with tutor or peer feedback on self-regulated learning and learning outcomes," Learning and Instruction (17:5), pp. 532-548.

Van Zundert, M., Sluijsmans, D., and Van Merriënboer, J. 2010. "Effective peer assessment processes: Research findings and future directions," Learning and Instruction (20:4), pp. 270-279.

Veerman, A. L., Andriessen, J. E. B., and Kanselaar, G. 2000. "Learning through synchronous electronic discussion," Computers \& Education (34:3-4), pp. 269-290.

Venkatesh, V., Morris, M. G., Gordon, B. D., and Davis, F. D. 2003. "User Acceptance of Information Technology: Toward a Unified View," MIS Quarterly (27:3), pp. 425-478.

Vom Brocke, J., White, C., Walker, U., and Vom Brocke, C. 2010. "Making User-Generated Content Communities Work in Higher Education-The Importance of Setting Incentives," in: Changing Cultures in Higher Education. Moving Ahead to Future Learning, Springer, 2010, pp. 149-166.

Vonderwell, S. 2003. "An examination of asynchronous communication experiences and perspectives of students in an online course: A case study," The Internet and Higher Education (6:1), pp. 77-90.

Wang, M. C., Haertel, G. D., and Walberg, H. J. 1990. "What influences learning? A content analysis of review literature," The Journal of Educational Research (84:1), pp. 30-43.

Winter, R. 2008. "Design science research in Europe," European Journal of Information Systems (17:5), pp. 470-475.

Winter, R. 2010. "Interview with Jay F. Nunamaker, Jr. on "Toward a Broader Vision of IS Research"," Business and Information Systems Engineering (5:5), pp. 321-329. 